\title{
Hylid or microhylid? No evidence for the occurrence of Trachycephalus mesophaeus (Anura, Hylidae) in Argentina
}

\author{
Julián FAIVOVICH \& Agustín J. ELIAS-COSTA
}

\begin{abstract}
División Herpetología, Museo Argentino de Ciencias Naturales "Bernardino Rivadavia"--CONICET, Ángel Gallardo 470, C1405DJR Buenos Aires, Argentina. E-mail: julian@macn.gov.ar
\end{abstract}

\begin{abstract}
A recent publication reported the Atlantic Forest endemic hylid Trachycephalus mesophaeus for the Chacoan ecoregion in Argentina. In this paper, we analyzed the voucher specimen and showed that it is a misidentified specimen of the Asiatic microhylid Kaloula pulchra, a species commonly commercialized in the pet trade worldwide. Therefore, there is no evidence for the occurrence of T. mesophaeus in Argentina.
\end{abstract}

Key words: Hylidae, Hylinae, Lophyohylini, Microhylidae, Kaloula, bizarre taxonomy

Resumen: Hílido o microhílido? No hay evidencia de la presencia de Trachycephalus mesophaeus (Anura, Hylidae) en Argentina. Una publicación reciente reportó al hílido endémico del Bosque Atlántico Trachycephalus mesophaeus para la ecoregión Chaqueña en Argentina. En este trabajo, analizamos el espécimen de referencia y demostramos que se trata de un ejemplar incorrectamente determinado del microhílido asiático Kaloula pulchra, una especie comercializada a nivel mundial. De esta forma, no existe evidencia para considerar que T. mesophaeus esté presente en Argentina.

Palabras clave: Hylidae, Hylinae, Lophyohylini, Microhylidae, Kaloula, taxonomía bizarra

\section{INTRODUCTION}

The hylid lophyohyline genus Trachycephalus Tschudi, 1838 includes 17 species (Blotto et al., in press) distributed from Mexico to central-eastern Argentina (Frost, 2020). Faivovich et al. (2005) recovered the type species of Trachycephalus, T. nigromaculatus Tschudi, 1838, nested among species of Phrynohyas Fitzinger, 1843, and redefined Trachycephalus to also include all species formerly included in that genus.

Two species of Trachycephalus have been considered to be present in Argentina: Trachycephalus dibernardoi Kwet \& Solé, 2008 and T. typhonius (Linnaeus, 1758). The former was initially reported by Carrizo (1989) as Phrynohyas imitatrix (Miranda-Ribeiro, 1926) for the interior Atlantic Forest in the province of Misiones, and subsequently considered to be T. dibernardoi by Kwet \& Solé (2008). More recently, Blotto et al. (in press) suggested that the distinction between both species needs to be reassessed. Trachycephalus typhonius has been recorded in Argentina (as Phrynohyas venulosa or Trachycephalus venulosus; see Lavilla et al.,
2010), in the provinces of Chaco, Corrientes, Entre Ríos, Formosa, Jujuy, Misiones, Salta, Santa Fe, and Santiago del Estero (Vellard, 1948; Cei, 1956, 1980; Martínez-Achenbach, 1961; Lavilla and Scrocchi, 1988). This species has a wide distribution, reaching Central America (Frost, 2020), and still requires a considerable taxonomic effort to elucidate how many different species are included under the name (Lavilla et al., 2010; Ron et al., 2016; Ferraro et al., 2018; Blotto et al., in press).

\section{THE NEW RECORD}

Recently, Garcia-Marsà et al. (2020) reported a third species of Trachycephalus for Argentina, T. mesophaeus (Hensel, 1867), based on a single specimen (CFA-An-88; Scientific collection of Fundación de Historia Natural "Félix de Azara", amphibians; Ciudad de Buenos Aires, Argentina) informed as collected in Las Lomitas, province of Formosa, on October 3, 1986. Trachycephalus mesophaeus (Fig. $1 \mathrm{~A}-\mathrm{D}$ ) is a species known to occur in the Atlantic Forest of Southeastern and Eastern Brazil, from the states of Rio Grande 
do Sul to Pernambuco (e.g., Kwet et al., 2010; Haddad et al., 2013). Garcia-Marsà et al. (2020) identified the specimen explicitly based on color pattern, and, very likely (see below) on the fact that the specimen had a label identifying it as "Trachycephalus sp." The authors pondered the possibility that it could belong to "a still unknown population of the T. typhonius complex". However, as they concluded that the specimen showed "all morphological attributes of T. mesophaeus", they considered it to belong to this species.

Once they established the identification of the specimen, Garcia-Marsà et al. (2020) discussed possible reasons why T. mesophaeus has not been collected in recent years in Argentina. They considered that the species might be difficult to find, and as the Chacoan ecoregion is still poorly explored, they hypothesized that perhaps there are still healthy populations of T. mesophaeus in the Chacoan ecoregion. Alternatively, they discussed the possibility that the species has been locally extinct due to the substantial degradation of this ecoregion. Garcia-Marsà et al. (2020) also discussed the biogeographic significance of their finding of an Atlantic Forest-endemic species in the transition zone of the humid and dry portions of the Chacoan ecoregion. They considered that it was not uncommon, based on the evidence of past connections between the Atlantic Forest and the Amazon basin. They further suggested that their finding of a "relictual population" of T. mesophaeus could reflect the past, widespread distribution of gallery forests and associated fauna.

\section{THE SPECIMEN}

The photographs provided by Garcia-Marsà et al. (2020: fig. 2) of the specimen that they identified as T. mesophaeus show a frog that has the following remarkable characters (all the information for Trachycephalus is from Duellman, 1971; Paolillo \& Cerdá, 1981; Pombal et al., 2003; Gordo et al., 2013; Nunes et al., 2013; Blotto et $a l .$, in press): (1) A large, darkly-pigmented single subgular vocal sac (vocal sacs in Trachycephalus are paired, bilateral or, less commonly, bilobular). (2) Absence of a tympanic membrane (all species of Trachycephalus have a prominent tympanic membrane). (3) Foot and hand webbing basal or absent (all species of Trachycephalus have a considerable amount of foot webbing, and evident hand webbing). (4) Non-expanded discs (all species of Trachycephalus have prominent discs in hands and feet). (5) Absence of nuptial pads, despite being an adult male as revealed by the dark-colored vocal sac (present in all species of Trachycephalus). (6) Presence of an expanded, spade-like inner metatarsal tubercle (oval, not expanded in Trachycephalus). (7) Short hindlimbs (hindlimbs proportionally larger in Trachycephalus). Briefly: the specimen does not even remotely look like a hylid, nor is it similar to any other anuran species occurring in Argentina.

The study of the specimen CFA-An-88 (Fig. $1 \mathrm{E}, \mathrm{F})$, besides corroborating all the characters that are evident in the published photographs, indicates that the specimen lacks maxillary and premaxillary teeth, and that it has two noticeable palatal folds. This combination of characters is only known to occur in anurans of the families Brevicipitidae and Microhylidae (Parker, 1934; Laurent, 1986).

From a purely taxonomic perspective, the specimen in question cannot be associated with Brevicipitidae as it lacks the very characteristic body shape and reduced mouth of the species in this family (see Channing \& Rödel, 2019), thus pointing at the widely-distributed, diverse family Microhylidae (690 species; Frost, 2020). This family currently includes 13 (de Sá et al., 2012; Peloso et al. 2016) or 12 subfamilies (Tu et al. 2018; Streicher et al., 2020). Although there has been considerable progress in defining its major clades, recent discussions on the phylogenetic relationships of the family have barely referred to phenotypic evidence or taxonomic aspects. For this reason, the taxonomic identification of a microhylid without locality data could be challenging. Fortunately, this was not the case, as this specimen belongs to one of the microhylid species most commonly available in the pet trade: Kaloula pulchra Gray, 1831.

Among microhylids, the specimen is attributable to the microhyline Kaloula pulchra due to the combination of the following characters (compare Figs. $1 \mathrm{E}, \mathrm{F}$ and $1 \mathrm{G}, \mathrm{H}$ ): Snoutvent length of $50-60 \mathrm{~mm}$ (the specimen is quite contorted and it is difficult to make a precise measurement) congruent with the size interval reported for adult males of this species, 54-72 mm, vs. smaller SVL in adult males of Adelastinae, Chaperininae, Hoplophryninae, Melanobatrachinae, and most species of Asterophryinae, Cophylinae, Gastrophryninae, and Scaphiophryninae); robust body; head wider than long with truncated snout (vs. acute, subtriangular in Gastrophryninae, Kalophryninae and Otophryninae); tympanic membrane absent; supratympanic fold present; absence of 


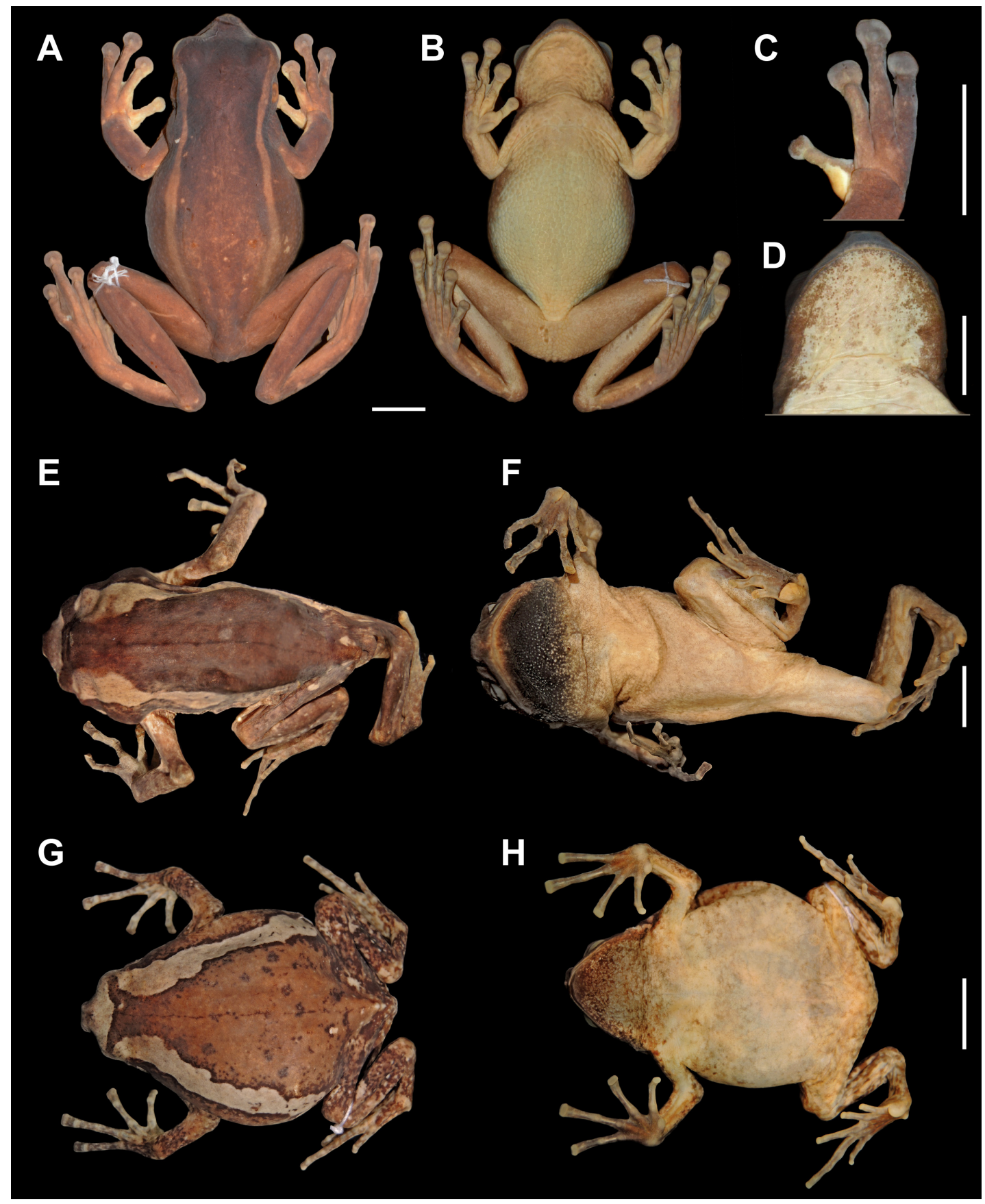

Fig. 1. A-B: Adult female of the hylid Trachycephalus mesophaeus LGE 10538 (Brazil: Rio Grande do Sul: Terra de Areia). C: Detail of nuptial pad, and D: gular region in ventral view of an adult male T. mesophaeus LGE 22305 (Brazil: São Paulo: Ubatuba). Vocal sacs are paired, lateral, and almost entirely restricted to the posttympanic region, with little subgular development, as evidenced by the lack of dark pigmentation in the area. E-F: Adult male of the microhylid Kaloula pulchra (CFA-An-88), the specimen identified as T. mesophaeus by Garcia-Marsà et al. (2020). G-H: Adult male Kaloula pulchra MACN-He 39171 (pet trade), a properly fixed and preserved specimen. Scale bars: $1 \mathrm{~cm}$. Abbreviations not used in the main text: LGE: Laboratorio de Genética Evolutiva, Instituto de Biología Subtropical, Universidad Nacional de Misiones, Posadas, Misiones, Argentina. 
maxillary, premaxillary, and vomerine teeth (vs. presence of teeth in Dyscophinae and most nonminute Cophylinae); two palatal folds; proportionally small hindlimbs; presence of a spade-like inner metatarsal tubercle; finger tips not expanded (vs. greatly expanded in many members of Asterophryinae, Cophylinae, Scaphiophryninae and Phrynomerinae); dark brown, smooth dorsal skin with light paired lateral bands; darkly-pigmented single subgular vocal sac (Parker, 1934; Inger, 1966; Zweifel, 1986; Glaw \& Vences, 2007; Du Preez \& Carruthers, 2009; Rittmeyer et al., 2012; Zug, 2015; Vassilieva et al., 2016; Garg \& Biju, 2019).

The distinctive dorsal pattern of the specimen, which consists of two light bands on the dorsolateral margins of the body, is also present in $K$. mediolineata, Uperodon anamalaiensis, and $U$. taprobanicus (Microhylinae) and Phrynomantis bifasciatus (Phrynomerinae). Kaloula pulchra differs from $K$. mediolineata, by the lack of a posterior middle-back stripe (Taylor, 1962), from the two species of Uperodon by its larger SVL and non-expanded discs in hands (Garg et al., 2018), and from Phrynomantis bifasciatus, for its lighter coloration, lack of ventral white blotches, larger forelimbs, longer toes, and dark gular pigmentation in adult males (Du Preez \& Carruthers, 2009; Channing \& Rödel, 2019).

\section{LAYERS OF CONFUSION}

Kaloula pulchra is a widely-distributed species, ranging from northern India to Vietnam, through Bangladesh, Myanmar, southern China, Thailand, and Laos, and south to Cambodia, Malaysia, Singapore, and Indonesia, and it has been introduced in the Philippines (Kuangyang et al., 2016; Pili et al., 2020; Frost, 2020). This species has been extensively commercialized in the pet trade, and imported to Argentina at least during the $1990 \mathrm{~s}$.

The specimen of Kaloula pulchra that Garcia-Marsà et al. (2020) misidentified as Trachycephalus mesophaeus is in a jar with a label indicating it as "Trachycephalus sp. Las Lomitas, Formosa. Col: José Soroca. 03/10/1995.” It is worth noting that there is no other specimen of this genus collected in Formosa housed in the collection of Fundación de Historia Natural Félix de Azara, although another species, T. typhonius has been collected in Las Lomitas (M. Duré, pers. comm.), and nearby localities in Formosa (e.g., Pozo del Tigre, MACN-He 54611; Colección Nacional de Herpetología, Museo Argentino de
Ciencias Naturales "Bernardino Rivadavia"CONICET, Ciudad de Buenos Aires, Argentina). Furthermore, S. Bogan (pers. comm.) indicated that the specimen was accessioned as part of material sporadically donated by the collector. Clearly, at some point, there was a human error, the label was associated with the wrong specimen, and triggered a series of confusions that ended up with Garcia-Marsà et al. (2020) wrongly reporting $T$. mesophaeus for the first time in Argentina. Nevertheless, the fact that the manuscript reporting the "new" record, including illustrations of the remarkably misidentified specimen, found its way through the conventional filters of scientific publication, is worrisome.

\section{ACKNOWLEDGMENTS}

We wish to highlight the fact that although Jordi A. Garcia-Marsà, Federico L. Agnolín, and Julia S. D'Angelo are affiliated with the Museo Argentino de Ciencias Naturales "Bernardino Rivadavia"-CONICET, they have no connection with the División Herpetología of this institution. We thank Sergio Bogan for granting access to the scientific collection of Fundación de Historia Natural Félix de Azara. Sonia Kretszchmar (Fundación Miguel Lillo) and Diego Baldo (Instituto de Biología Subtropical, CONICET-UNaM) kindly answered our requests of information regarding their collection holdings of Trachycephalus from Formosa. Marta Duré (Centro de Ecologia Aplicada del Litoral, CONICET-UNNE) shared unpublished data of herpetofaunal surveys in Formosa. Diego Baldo kindly produced the photos of Trachycephalus mesophaeus included in Fig. 1. The manuscript was read and improved by Katyuscia AraujoVieira, Boris Blotto, Laura Nicoli, and Martín O. Pereyra. Diego Baldo, Esteban O. Lavilla, and the editor provided useful comments. We thank ANPCyT (PICT 820-2015) and FAPESP (procs. 2013/50741-7, 2018/15425-0) for the financial support.

\section{REFERENCES}

Blotto, B.L., Lyra, M.L., Cardoso, M.C.S, Rodrigues, M.T., Ribeiro Dias, I., Marciano-Jr., E., Dal Vechio, F., Orrico, V.G.D., Brandão, R.A., Assis, C.L., LantyerSilva, A.S.F., Rutherford, M.G., Gagliardi-Urrutia, G., Solé, M., Baldo, D., Nunes, I., Cajade, R., Torres, A., Grant, T., Jungfer, K.-H., Silva, H.R., Haddad, C.F.B., \& Faivovich, J. In press. The phylogeny of the Casque-headed Treefrogs (Hylidae: Hylinae: Lophyohylini). Cladistics. DOI 10.1111/cla.12409 
Carrizo, G.R. 1989. Un nuevo hílido (Amphibia: Anura) para la Argentina, Phrynohyas imitatrix (Miranda Ribeiro, 1926). Boletín de la Asociación Herpetológica Argentina 5: 9-10.

Cei, J. M. 1956. Nueva lista sistemática de los batracios de Argentina y breves notas sobre su biologia y ecologia. Investigaciones Zoológicas Chilenas 3: $35-68$.

Cei, J. M. 1980. Amphibians of Argentina. Monitore Zoologico Italiano (New Series) Monographs 2: 1-609.

Channing, A. \& Rödel, M.-O. 2019. Field guide to the frogs and other amphibians of Africa. Struik Nature, Cape Town.

de Sá, R.O., Streicher, J.W., Sekonyela, R., Forlani, M.C., Loader, S.P., Greenbaum, E., Richards, S., \& Haddad, C.F.B. 2012. Molecular phylogeny of microhylid frogs (Anura: Microhylidae) with emphasis on relationships among New World genera. BMC Evolutionary Biology 12(1): 241.

Du Preez, L.H. \& Carruthers, V.C. 2009. A complete guide to the frogs of Southern Africa. Cape Town, South Africa: Random House Struik; $1^{\text {st }}$ ed. 488 p.

Duellman, W.E. 1971. A taxonomic review of South American hylid frogs, genus Phrynohyas. Occasional Papers of the Museum of Natural History, The University of Kansas 4: 1-21.

Faivovich, J., Haddad, C.F.B., Garcia, P.C.A., Frost, D.R., Campbell, J.A., \& Wheeler, W.C. 2005. Systematic review of the frog family Hylidae, with special reference to Hylinae: phylogenetic analysis and taxonomic revision. Bulletin of the American Museum of Natural History 294: 1-240.

Ferraro, D.P.; Blotto, B.; Baldo, D.; Barrasso, D.; Barrionuevo, S.; Basso, N.; Cardozo, D.; Cotichelli, L.; Faivovich, J.; Pereyra, M. \& Lavilla, E.O. 2018. Sistemática y Diversidad. En: Plan de Acción para la Conservación de los Anfibios de la República Argentina. Cuadernos de Herpetología 32 (supl. 1): 15-19. doi: 10.31017/CdH.2018.(2018-s1).

Fitzinger, L.J.F. J. 1843. Systema Reptilium. Fasciculus Primus. Wien: Braumüller et Seidel.

Frost, D.R. 2020. Amphibian Species of the World: an Online Reference. Version 6.1. Electronic Database accessible at https://amphibiansoftheworld.amnh.org/index.php. American Museum of Natural History, New York, USA.

Garcia-Marsà, J.A., Agnolín, F.L., \& D’Angelo, J.S. 2020. First country record of Trachycephalus mesophaeus (Hensel, 1867) (Amphibia, Anura, Hylidae). Check List 16: 219-222.

Garg, S. \& Biju, S.D. 2019. New microhylid frog genus from Peninsular India with Southeast Asian affinity suggests multiple Cenozoic biotic exchanges between India and Eurasia. Scientific Reports 9(1): 1906.

Garg, S., Senevirathne, G., Wijayathilaka, N., Phuge, S., Deuti, K., Manamendra-Arachchi, K., Meegaskumbura, M. \& Biju, S.D. 2018. An integrative taxonomic review of the South Asian microhylid genus Uperodon. Zootaxa 4384(1): 1-88.

Glaw, F. \& Vences, M. 2007. A Field Guide to the
Amphibians and Reptiles of Madagascar. 3rd ed. Vences \& Glaw Verlag, Köln, Germany.

Gordo, M., Toledo, L.F., Suárez, P., Kawashita-Ribeiro, A., Ávila, R.W., Morais, D.H. \& Nunes, I. 2013. A new species of milk frog of the genus Trachycephalus Tschudi (Anura, Hylidae) from the Amazonian rainforest. Herpetologica 69: 466-479.

Gray, J.E. 1831. Description of two new genera of frogs discovered by John Reeves, Esq. in China. Zoological Miscellany 1: 38.

Haddad, C.F.B., Toledo, L.F., Prado, C.P.A., Loebman, D., Gasparini, J.L., \& Sazima, I. 2013. Guia dos anfíbios da Mata Atlântica: diversidade e biologia. Anolis Books, São Paulo.

Hensel, R.F. 1867. Beiträge zur Kenntnis der Wirbelthiere Südbrasilens. Archiv für Naturgeschichte 33: $120-162$.

Inger, R.F. 1966. The systematics and zoogeography of the Amphibia of Borneo. Fieldiana Zoology 52: $1-402$.

Kuangyang, L., Zhigang, Y., Haitao, S., Baorong, G., van Dijk, P.P., Iskandar, D., Inger, R.F., Dutta, S., Sengupta, S., Uddin Sarker, S., \& Asmat, G. 2004. Kaloula pulchra (errata version published in 2016). The IUCN Red List of Threatened Species, e.T57855A86163405.

Kwet, A. \& Solé, M. 2008. A new species of Trachycephalus (Anura: Hylidae) from the Atlantic rain forest in southern Brazil. Zootaxa 1947: 5367.

Kwet, A., Lingnau, R., \& Di-Bernardo, M. 2010. PróMata: Anfibios da Serra Gaúcha, sul do Brasil. Bazilien-Zentrum, University of Tubingen, Germany. 148 pp. 200 figs. $2^{\text {nd }}$, revised edition.

Laurent, R.F. 1986. Sous classe de Lissamphibiens: Lissamphibia Systématique. In: Grassé, P.-P., Delsol, M. (Eds.), Traité de Zoologie: Anatomie, Systématique, Biologie, Tome XIV. Masson, Paris, pp. 594-797.

Lavilla, E.O. \& Scrocchi, G.J. 1988. Geographic distribution: Phrynohyas venulosa. Herpetological Review 19(3): 59.

Lavilla, E.O., Langone, J.A., Padial, J.M., \& de Sá, R.O. 2010. The identity of the crackling, luminescent frog of Suriname (Rana typhonia Linnaeus, 1758) (Amphibia, Anura). Zootaxa 2671: 17-30.

Martínez-Achenbach, G. 1961. Nota acerca de batracios nuevos para la provincial de Santa Fe. Primera Reunión de Trabajos y Comunicaciones de Ciencias Naturales y Geografia del Litoral. Instituto del Profesorado Básico, Universidad Nacional del Litoral, pp. 63-72.

Miranda-Ribeiro, A. 1926. Notas para servirem ao estudo dos gymnobatrachios (Anura) brasileiros. Archivos do Museu Nacional 27: 1-227.

Nunes, I., Suárez, P., Gordo, M., \& Pombal Jr, J.P. 2013. A second species of Trachycephalus Tschudi (Anura: Hylidae) with a single vocal sac from the Brazilian Amazon. Copeia 2013: 634-640.

Paolillo, A.O. \& Cerda, J. 1981. Nuevos hallazgos de Aparasphenodon venezolanus (Mertens) (Salientia, Hylidae) en el territorio federal Amazonas, 
Venezuela, con anotaciones sobre su biología. Memoria de la Fundación La Salle de Ciencias Naturales 41: 77-95.

Parker, H.W. 1934. A monograph of the frogs of the family Microhylidae. British Museum (Natural History), London.

Peloso, P.L., Frost, D.R., Richards, S.J., Rodrigues, M.T., Donnellan, S., Matsui, M., Raxworthy, C.J., Biju, S.D, Moriarty Lemmon, E., Lemmon, A.R., \& W.C. Wheeler, W.C. 2016. The impact of anchored phylogenomics and taxon sampling on phylogenetic inference in narrow-mouthed frogs (Anura, Microhylidae). Cladistics 32: 113-140.

Pili, A.N., Sy, E.Y., Diesmos, M.L.L., \& Diesmos, A.C. 2019. Island hopping in a biodiversity hotspot archipielago: reconstructed invasion history and updated status and distribution of alien frogs in the Philippines. Pacific Science 73: 321-343.

Pombal Jr, J.P., Haddad, C.F.B., \& Cruz, C.A.G. 2003. New species of Phrynohyas from Atlantic rain forest of southeastern Brazil (Anura, Hylidae). Copeia 2003: 379-383.

Rittmeyer, E.N., Allison, A., Gründler, M.C., Thompson, D.K., \& Austin, C.C. 2012. Ecological guild evolution and the discovery of the world's smallest vertebrate. PLoS One 7(1).

Ron, S.R., Venegas, P.J., Ortega-Andrade, H.M., Gagliardi-Urrutia, G., Salerno, P.E., 2016. Systematics of Ecnomiohyla tuberculosa with the description of a new species and comments on the taxonomy of Trachycephalus typhonius (Anura, Hylidae). Zookeys 630, 115-154.
Streicher, J.W., Loader, S.P., Varela-Jaramillo, A., Montoya, P., \& de Sá, R.O. 2020. Analysis of ultraconserved elements supports African origins of narrow-mouthed frogs. Molecular Phylogenetics and Evolution 146: 106771.

Taylor, E.H. 1962. The amphibian fauna of Thailand. University of Kansas Science Bulletin 63: 265-599.

Tschudi, J.J.v. 1838. Classification der Batrachier mit Berücksichtigung der fossilen Thiere dieser Abtheilung der Reptilien. Neuchâtel: Petitpierre.

Tu, N., Yang, M., Liang, D., \& Zhang, P. 2018. A large-scale phylogeny of Microhylidae inferred from a combined dataset of 121 genes and 427 taxa. Molecular phylogenetics and evolution 126: 85-91.

Vassilieva, A., Galoyan, E.A., Poyarkov-Jr., N.A., Geissler, P. 2016. A photographic field guide to the amphibians and reptiles of the lowland monsoon forests of southern Vietnam. Chimaira, Frankfurt am Main.

Vellard, J. 1948. Batracios del Chaco Argentino. Acta Zoologica Lilloana 5: 137-174.

Zug, G.R. 2015. Morphology and systematics of Kalophrynus interlineatus-pleurostigma populations (Anura: Microhylidae: Kalophryninae) and a taxonomy of the genus Kalophrynus Tschudi, Asian sticky frogs. Proceedings of the California Academy of Sciences 62: 135-190.

Zweifel, R.G. 1986. A new genus and species of microhylid frog from the Cerro de la Neblina region of Venezuela and a discussion of relationships among New World microhylid genera. American Museum Novitates 2847: 1-24.

Doi: 10.22179/REVMACN.20.683

Recibido: 2-IV-2020

Aceptado: 9-IV-2020 